Revista Iberoamericana, Vol. LXXVIII, Núm. 241, Octubre-Diciembre 2012, 1027-1042

\title{
INCITACIÓN A LA HERMENÉUTICA EN LA NARRATIVA DE ONETTI
}

\author{
POR \\ Diego Alonso \\ Reed College
}

Claro está, para nosotros, que el verbo entender, aplicado a cualquier expresión artística, no entraña exclusivamente una comprensión lógica.

Juan C. Onetti, "Reflexiones literarias”

I. La literatura de Onetti plantea un reto hermenéutico al romper con la expectativa de una articulación dialéctica entre la comprensión y la explicación de aquello que narra. Aceptar este reto implica, de acuerdo al marco teórico de este trabajo, considerar de conjunto la dimensión simbólica presente en los relatos, aquellas escenas que motivan y ponen en funcionamiento el acto de la enunciación, y la conversión metafórica que revela parcialmente su sentido. ${ }^{1} \mathrm{Si}$ indico el carácter parcial de tal esclarecimiento es porque hay en dichas escenas, como en toda configuración simbólica verdadera, un elemento no semántico, irreductible, que echa raíces en las "profundidades de la experiencia humana” (Ricoeur, Teoría 82). El lector es confrontado así con algo intraducible que excede el lenguaje y hace fracasar cualquier intento de reducción conceptual. Un texto tras otro, los narradores del corpus onettiano repiten la promesa de haber alcanzado, ellos mismos o los eventuales personajes de sus historias, un entendimiento que no admite explicación: una forma de existencia que nada tiene que ver con la búsqueda premeditada y metódica. Para dar un ejemplo, eso es lo experimentado por Risso, el trágico protagonista de "El infierno tan temido":

Volteado en la cama, Risso creyó que empezaba a comprender, que, como una enfermedad, como un bienestar, la comprensión ocurría en él, liberada de la voluntad

\footnotetext{
1 El marco teórico al que hago referencia se constituye, principalmente, a partir de los postulados hermenéuticos de Paul Ricoeur; en el curso de mi análisis, remitiré a dos libros suyos traducidos al español: Teoría de la interpretación. Discurso y excedente de sentido y Hermenéutica y acción. De la hermenéutica del texto a la hermenéutica de la acción. Para una aproximación sistemática a su obra, me ha sido útil el estudio de Vicente Balaguer, La interpretación de la narración. La teoría de Paul Ricoeur.
} 
y de la inteligencia. Sucedía, simplemente, desde el contacto de los pies con los zapatos hasta las lágrimas que le llegaban a las mejillas y al cuello. La comprensión sucedía en él, y no estaba interesado en saber qué era lo que comprendía, mientras recordaba o estaba viendo su llanto y su quietud, la alargada pasividad del cuerpo en la cama, la comba de las nubes en la ventana, escenas antiguas y futuras. (Onetti 1305)

Son frases como éstas las que plantean el reto hermenéutico y recuerdan a la crítica que opera en un plano en cierta medida distinto al de la creación literaria. El elemento intraducible -no semántico- de lo simbólico, que suscita en distintos ámbitos (psicoanalítico, religioso, literario) una confabulación entre la fuerza y la forma capaz de iluminar la invención poética y ofrecer nuevas perspectivas (Ricoeur, Teoría 7076), constituye, pues, un ineludible desafío interpretativo. Es que a diferencia de la obra de creación, la crítica no sólo debe abocarse a “comprender”, sino también hacer comprensible el mundo abierto por el texto.

Es sabido que el reclamo de una dialéctica de la comprensión y la explicación constituye uno de los ejes del pensamiento crítico de Ricoeur, para quien ambas operaciones son indisociables de un mismo proceso hermenéutico: "explicar más es comprender mejor” (Balaguer 51). Esta propuesta tiene importancia para la crítica ya que en torno a la cuestión del sentido y de la referencia, y en un esfuerzo por clarificar la especificidad y hacer coincidir los ámbitos de la semiótica y de la semántica, Ricoeur postula una mejor adecuación entre subjetividad interpretativa y objetividad metodológica, destacando la relevancia del texto en tanto instancia reveladora de un mundo en que el sujeto podría descubrirse y experimentar "nuevos modos de ser" (Teoría 106). ${ }^{2}$ Se conjuga de este modo una hermenéutica de orden ontológico, en la que comprender es un modo de ser en el mundo, con un análisis estructural, explicativo, de los textos.

La adopción de este paradigma teórico-metodológico está motivado en una lectura que trasciende "Un sueño realizado" (1941), cuento sobre el que se concentrarála segunda parte de este trabajo. La obra de Onetti es rica en escenas cuya densidad simbólica reclama insidiosamente una interpretación; un pensar más, diría Ricoeur, que implica la apertura de un proceso, a la vez, de apropiación (autocomprensiva) y clarificación semántica. Tales escenas suelen constituir la matriz de todo un relato que se despliega

\footnotetext{
2 "No la intención del autor, que está oculta detrás del texto; no la situación histórica común al autor y sus lectores originales; no las expectativas o sentimientos de estos lectores originales; ni siquiera la comprensión de sí mismos como fenómenos históricos y culturales. Lo que tiene que apropiarse es el sentido del texto mismo, concebido en forma dinámica como la dirección que el texto ha impreso al pensamiento. En otras palabras, lo que tiene que ser apropiado no es otra cosa que el poder de revelar un mundo que constituye la referencia del texto. De esta manera estamos tan lejos como es posible del ideal romántico de coincidir con una psique ajena. Si se puede decir que coincidimos con algo, no es con la vida interior de otro ego, sino con la revelación de una forma posible de mirar las cosas, lo que constituye el genuino poder referencial del texto" (Ricoeur, Teoría 104).
}

Revista Iberoamericana, Vol. LXXVIII, Núm. 241, Octubre-Diciembre 2012, 1025-1040
ISSN 0034-9631 (Impreso) 
impulsado por la voluntad de entender. Valgan como recuerdo de estos disparadores de historias el sueño de la cabaña de troncos en El pozo (1939); el descubrimiento de Rita y el chivo en Para una tumba sin nombre (1959); la evocación de Moncha, vestida de novia detrás de los muros de un jardín nocturno, en "La novia robada” (1968); las fotos abyectas que recibe Risso en "El infierno tan temido" (1957); o bien, este otro sueño que busca representar en un escenario la mujer del cuento que analizaré. Alrededor de estas historias mínimas se van tejiendo versiones, indagaciones semánticas convendría decir, en las que participan los distintos narradores del corpus para concluir negativamente, al menos en lo que concierne la validación del sentido. Así lo expresa Díaz Grey en el final de Para una tumba sin nombre: "Ignoraba el sentido de lo que había visto, me era repugnante la idea de averiguar y cerciorarme” (Onetti 1045). Sin embargo, la negatividad declarada no impide afirmar en ésta y en otras historias, de manera más o menos explícita, alguna forma de entendimiento o, en todo caso, la apertura de un plano de comprensión (el texto producido) incitador de nuevas búsquedas. Luego de haber declarado como casi único hallazgo "una confusión sin esperanza, un relato sin final posible, de sentidos dudosos" (1045), el narrador declara un "sentimiento de paz" y afirma el valor de su función: "había aceptado un desafío, había convertido en victoria por lo menos una de las derrotas cotidianas" (1046). ${ }^{3}$

Más de un estudio crítico ha retenido lo visual como rasgo predominante de la narrativa onettiana, lo que convertiría ésta en una escenificación a partir de imágenes. ${ }^{4}$ Presentadas como "prólogos" del acto narrativo, estas imágenes de inocultable densidad simbólica son el motivo de la "verdadera historia" (Onetti 1278). Ellas agregan un plano a la realidad de la ficción, pasando de la "nada" que antecede la escritura a la representación de seres y situaciones por lo general insólitos que, de no mediar la conversión metafórica, el lector comprendería sólo muy parcialmente o, incluso, no atinaría siquiera a comprender. ${ }^{5}$ El texto se crea, así, en una tensión con la imagen que, dada su irreductibilidad a la escritura, no se puede explicar si no es a riesgo de destruir su luz estética, su efectividad. ${ }^{6}$ Por otra parte, la fuerza persuasiva de estas imágenes, su capacidad de remitir a una referencialidad con la que chocaría el acto narrativo, llevan a pensar el estatuto de la verdad y la cuestión de la verosimilitud en la literatura de Onetti.

3 Julio Premat indica un camino para la crítica enfrentada a ese "no saber” de la literatura onettiana: "Más allá de la ‘visión del mundo,’ más allá de un trabajo autoreferencial con la literatura, algo se juega en estos grises relatos de Onetti, que es tan terrible como aparentemente enigmático. Y aunque no se pueda 'saber' lo que sucede en los textos, pienso que ese 'no saber', puede, si no saberse, al menos interpretarse” (525).

4 Véase Ludmer (86), Ferro (117), Premat (520) y Verani (9-22).

5 Es de notar que Ricoeur, a la par de rescatar la función esclarecedora de la metáfora en relación al símbolo, afirma el elemento no semántico de éste, dando lugar a una dualidad valorativa que, por otra parte, se encuentra a la base de la dialéctica de la comprensión y la explicación véase Teoría de la interpretación (82).

6 Véase Chartier (92).

Revista Iberoamericana, Vol. LXXVIII, Núm. 241, Octubre-Diciembre 2012, 1025-1040 ISSN 0034-9631 (Impreso) 
“Elálbum”(1953) es un elocuente comentario de la tensión referida, dando expresión al siguiente principio narrativo: el relato desprovisto de imágenes, sin referencia a la visión, no puede ser creído. “Sólo el ‘ver personalmente’-escribe Ludmer-puede compararse, en su estatuto de verdad ('ver para creer'), con la invención, con lo creado” (183-184). La ficción se cuenta siempre a partir de imágenes, pero sobre éstas se ha de llevar a cabo un trabajo de escritura, es decir, de invención. ${ }^{7}$ La mera copia es desechada como traición a una poética. Las fotos que Jorge Malabia descubre al final de este relato son declaradas infamantes porque muestran el referente exacto de cada una de las historias que la invariable y enigmática mujer le había contado; muestran la no ficcionalidad de éstas y anulan retrospectivamente el goce de haberlas escuchado:

En cuclillas, envejecido, tratando de manejar la pipa con evidente soberbia, vi las fotografías en que la mujer -menos joven y más crédula a medida que iba pasando las páginas-cabalgaba en Egipto, sonreía a jugadores de golf en un prado escocés, abrazaba actrices de cine en un cabaret de California, presentía la muerte en el ventisquero del Ruan, hacía reales, infamaba cada una de las historias que me había contado, cada tarde en que la estuve queriendo y la escuché. (1286)

Sólo la invención poética acerca el relato a la realidad (y recuerdo al pasar el contrapunto establecido en este cuento entre la voz narrativa y los lenguajes convencionales del periodístico y de los prospectos medicinales). Mímesis y poíesis se presentan unidos hasta llegar a confundirse, debiendo sustraerse del primero de estos términos una connotación realista de copia o reflejo. ${ }^{8}$ Como recuerda Ricoeur, la mímesis, de acuerdo a la comprensión que tenían los griegos, designaba "la referencia no ostensiva de la obra literaria o, en otros términos [...], la apertura-descubrimiento del mundo" (Hermenéutica 55). Se habla aquí del poder de significación del texto, de su habilidad

\footnotetext{
7 Podrían traerse a colación, igualmente, las fotografías de “El infierno tan temido”. Hay en ellas una construcción deliberada (escenarios, luces y poses) que las relacionan con lo teatral y colocan el tema de la creencia al centro del relato. La narración conjetura sobre el sentido y, por así decir, la condición de posibilidad de estas fotos y el soplo de abyección que ellas despiden. ¿Cómo hacer creíbles estas “imágenes excesivas”? Ya en pretéritos retratos publicados por carteleras teatrales, Gracia César, la mujer que le envía a Risso y luego al entorno de Risso las fotos abyectas, "mostraba la esperanza de convencer y ser comprendida” (1294-1295), anticipando el desenlace trágico de su relación con éste. Las fotos abren un “plano mágico” (1298), una forma de diálogo que prescinde del lenguaje para alcanzar algún tipo de comprensión; y Risso puede ver en las fotos que la Gracia de ahora, la que comete la iniquidad de enviarle esas imágenes, es la misma que la Gracia del pasado, que lo había amado y aún lo amaba: "Sin permitirse palabras ni pensamientos, se vio forzado a empezar a entender; a confundir a la Gracia que buscaba y elegía hombres y actitudes para las fotos, con la muchacha que había planeado, muchos meses atrás, vestidos, conversaciones, maquillajes, caricias a su hija para conquistar un viudo aplicado al desconsuelo, a este hombre que ganaba un sueldo escaso y que sólo podía ofrecer a las mujeres una asombrada, leal, incomprensión” (1302-1303).

8 Véase Ricoeur, Hermenéutica (55).
}

Revista Iberoamericana, Vol. LXXVIII, Núm. 241, Octubre-Diciembre 2012, 1025-1040
ISSN 0034-9631 (Impreso) 
poética, metafórica, para imitar creativamente la realidad. En este sentido, creo necesario pensar el recurso a la imagen en Onetti como el núcleo productor de una compleja referencialidad. Todo se jugaría en la justa distancia que la narración mantiene con ella: si es demasiado cercana y devuelve un concepto previsible, anecdótico, de la realidad se decreta el fracaso de la empresa estética. Esto explica, por ejemplo, la desilusión de Jorge Malabia cuando al escuchar la historia de San Francisco que le cuenta la mujer de "El álbum" reconoce "su parecido con un aviso de bebidas en una de las revistas extranjeras que llegan al diario" (1281).

La realidad en la literatura de Onetti es la realidad interna al texto que la crítica hermenéutica ha de abordar como un espacio de producción semántica a la vez autónomo e irradiante. No corresponde a la crítica buscar un sentido único dentro del exceso propio al texto, sino de reemprender su proceso de semantización a partir de una lectura que se apropie objetiva e intuitivamente de los sentidos abiertos por una literatura, por lo demás, altamente paródica. Se postula, entonces, una lectura que sería constitutiva e innovadora respecto al sentido; lo cual estaría motivado en una narrativa que, como se ha visto, hace coincidir la invención de la fábula (poíesis) y la interpretación de ésta (hermenéutica). Santa María, la ciudad mítica, llama a la interpretación no sólo del lector, sino también de su mismo creador que desconoce el sentido de su creación; en palabras de Juan José Saer: "Santa María es un territorio inacabado por definición y, antes de introducir en él un nuevo elemento, Brausen no sabe cómo será ni cuál será su sentido” (217). Con esto, no se busca negar la relación entre el mundo del texto y la realidad exterior. El texto no es un sistema cerrado; leerlo de ese modo sería propio de una aproximación estructuralista, contraria a la que postulamos. ${ }^{9}$ Más bien, como se desprende de la lúcida lectura de Saer, el tratamiento referencial de la literatura de Onetti establece una continuidad con ciertos autores del Siglo de Oro (Saer menciona a Cervantes y a Calderón de la Barca), cuyos mundos ficticios, y abismales, hicieron visible la permeabilidad de las fronteras entre la ficción y la realidad: la suya es "la realidad de la ficción” (236).

Aceptar entonces el "desafío” del cual hablaba Díaz Grey al fin de Para una tumba sin nombre es tratar de develar la confusa unidad simbólica, el contenido oscuro de esas escenas "de incierto factor no lingüístico o pre-lingüístico" (Ricoeur, Hermenéutica 21) asociadas tantas veces a los sueños. En otras palabras, habría que volver a recorrer el camino transitado por la escritura, detenerse en los símbolos que la motivan y su misterio latente, para concretizar (explicar) su sentido implícito. Esa sería la tarea aquí propuesta: dilucidar la relación entre los niveles semánticos y presemánticos referidos, destacando la estructura lingüística en la que dichos niveles se proyectan y clarifican.

9 Acerca de las diferencias que presenta la hermenéutica de Ricoeur con el estructuralismo, ver Balaguer (59-62).

\footnotetext{
Revista Iberoamericana, Vol. LXXVIII, Núm. 241, Octubre-Diciembre 2012, 1025-1040 ISSN 0034-9631 (Impreso) 
El objetivo crítico presentado puede sintetizarse como un esfuerzo dialéctico por fundar una objetividad que contemple una dimensión subjetiva de la comprensión. Para Ricoeur, esto es hablar de una "semántica profunda", resultado de un análisis estructural que permita "algún tipo de captación intuitiva de la intención que subyace al texto” (Teoría 100). Se debe reconfigurar la estructura inmanente del texto y, a la vez, comprender el mundo abierto por él, escapando a su propia clausura. No está de más recordar que, para la rama ontológica de la filosofía hermenéutica (Heidegger, Gadamer), el entendimiento no es el resultado una serie de operaciones que restituirían el sentido de la cosa dicha, sino más bien una manera que tiene el ser de estar en el mundo. De modo análogo, las indagaciones semánticas ya observadas en el interior de la narrativa de Onetti desembocan en un entendimiento que recusa la "comprensión lógica”, dando lugar a un entendimiento en sí en el que, expresado en código gadameriano, el comprender se confunde con lo comprendido. ${ }^{10}$

Para completar este razonamiento, quisiera considerar algunas palabras de Eladio Linacero, el narrador de El pozo:

¿Por qué hablaba de comprensión, unas líneas antes? Ninguna de esas bestias sucias puede comprender nada. Es como una obra de arte. Hay solamente un plano donde puede ser entendida. Lo malo es que el ensueño no trasciende, no se ha inventado la forma de expresarlo, el surrealismo es retórica. Sólo uno mismo, en la zona del ensueño de su alma, algunas veces. (Onetti 60)

El pasaje dice con bastante claridad lo que tiene que decir, sobre todo si se tiene en cuenta que El pozo, texto inaugural del corpus Onetti, se presenta como un relato alternativo de los sueños de Linacero y de los "sucesos" (inventados) que los habrían precedido. Y aunque está en la condición de los sueños llamar a una interpretación, queda descartada la adjudicación de un sentido que se fijaría de una vez para siempre en el momento de la escritura. ${ }^{11}$ Tampoco parece que se sugiriera la virtud de una pluralidad o relativismo semánticos que cedería la autoridad exclusiva a la instancia de la recepción. ${ }^{12}$ La imposibilidad de expresar adecuadamente el sueño y traducir su

10 No es cuestión, obviamente, de restituir un sentido oculto que expresaría la subjetividad del autor (Schleiermacher), sino más bien de asumir la existencia de un campo de significación simbólica que sería refractario a la definición y exige asumir la abundancia y ambigüedad semántica, sin desertar el conflicto de interpretaciones.

${ }^{11}$ Obsérvese que Linacero se refiere a estos sueños como si no tuvieran un sentido específico para él (Onetti 51). Lo mismo, veremos más adelante, se dice del sueño que quiere representar la mujer de "Un sueño realizado".

12 Comparto en términos generales el análisis de Ángel Rama sobre el rol que le estaría reservado al lector de Onetti: "Se trata de construir un elemento literario cuya resolución sea sólo posible mediante la sagacidad de una lectura capaz de combinar libremente los elementos puestos en juego, rearticularlos, conferirles un significado y levantar al fin la obra como invención propia de quien la ha leído”. Pero luego

Revista Iberoamericana, Vol. LXXVIII, Núm. 241, Octubre-Diciembre 2012, 1025-1040
ISSN 2154-4794 (Electrónico) 
sentido, remite a una estructura narrativa compensatoria que, pese a su carácter abstracto, puede entreabrir las puertas de la inteligibilidad. Me refiero al mito, cuya estructura, como recuerda Northrop Frye, crea una cadena simbólica de comprensión a partir de la alianza del sueño y del ritual (106-107).

El sentido profundo de la imagen sobre la que se construye el entramado ficcional de El pozo no puede ser comunicado verbalmente, pero ella aporta no obstante la cuota de belleza necesaria a la escritura:

Lo que yo siento cuando miro a la mujer desnuda en el camastro no puede decirse, yo no puedo, no conozco las palabras. Esto, lo que siento, es la verdadera aventura. Parece idiota, entonces, contar lo que menos interés tiene. Pero hay belleza, estoy seguro, en una muchacha que vuelve inesperadamente, desnuda, una noche de tormenta, a guarecerse en la casa de leños que uno mismo se ha construido, tantos años después, casi en el fin del mundo. (57)

La imagen alude, igualmente, a sentimientos o deseos que hablan de la recuperación de un tiempo perdido. La escritura se instala de esta manera en el tiempo del mito y el narrador, repitiendo una metáfora recurrente de la literatura onettiana, cuenta la escena “como contaría un sueño extraordinario si fuera un niño” (57). Quedaría por decir que lo estático de la imagen contribuye a la suspensión temporal, a la captura del tiempo ido en el presente, que sería propia del mito.

Alguna vez, Onetti expresó su admiración más alta por Proust (llegó a ofrecer todos los nombres de la literatura latinoamericana a cambio por el de este único autor), quien sitúa su obra en un tiempo poblado de recuerdos, sólo recuperable en ese sueño voluntariamente soñado que es la literatura. Se trataría de simular una vuelta a los orígenes, a una edad perdida que, como dice bien Pierre Albouy, es el “de la mythologie vécue” (338). En este intento de recuperación se vuelve a encender el mundo del sueño y la imaginación, dando lugar a un entendimiento que se muestra refractario a la razón. Este rápido comentario sobre el mito literario nos coloca en el umbral del cuento que quiero analizar.

II. “Un sueño realizado”, como muchos otros relatos de Onetti, narra un aprendizaje paradójico; el hallazgo de un saber intransferible, o mejor, cuyo sentido resulta imposible

de acordarle al lector esta función aparentemente plenipotenciaria, subraya el crítico: "Tampoco se trata de textos aleatorios y de plurales lecturas sustitutivas. No es ese el camino onettiano, visto que él cree firmemente que existe, entre las mil lecturas posibles, una sola válida, que es la suya propia. En vez de proponerla explícitamente, obligando así al lector a ser meramente quien obedece la conciencia del autor, construye delicada y oscilantemente el edificio literario para que el lector lo rearticule y le confiera el significado que el autor se rehúsa a proponer imperativamente” (Rama, “El narrador” 83).

Revista Iberoamericana, Vol. LXXVIII, Núm. 241, Octubre-Diciembre 2012, 1025-1040 ISSN 0034-9631 (Impreso) 
de explicar mediante el lenguaje. ${ }^{13}$ El narrador, un mediocre director de teatro llamado Langman que pasa los últimos años de su vida recluido en un asilo, recuerda un episodio de su carrera en el que una extraña mujer, una mujer de edad incierta, lo fuera a ver para pedirle de llevar a las tablas un sueño suyo en apariencia muy simple, pero que albergaba un desenlace trágico. Reflexionando sobre los posibles significados de esta historia, Langman concluye, repitiendo substancialmente algo que ya había dicho en páginas anteriores: “[...] comprendí qué era aquello [...]: lo comprendí todo claramente como si fuera una de esas cosas que se aprenden para siempre desde niño y no sirven después las palabras para explicar” (1219). ${ }^{14}$

Pero Langman, ha de saberse, no es el único confrontado a las dificultades del acto de entender. También Blanes, el otro personaje masculino de importancia en el cuento, se interroga con igual o, incluso, mayor grado de intensidad sobre el sentido del sueño y el comportamiento de la obstinada protagonista que, determinada en realizar su proyecto, no ceja ante ningún esfuerzo de disuasión. Nadie entiende en principio muy bien lo que significa el intento de la mujer ya que la escena finalmente representada ocupa sólo un instante y en ella, como si se aludiera metonímicamente a toda la literatura de Onetti, ocurre muy poco o casi nada. Le dice la mujer a Langman la primera vez que le explica lo que quiere representar:

-No, es todo distinto a lo que piensa. Es un momento, una escena se puede decir, y allí no pasa nada, como si nosotros representáramos esta escena en el comedor y yo me fuera y ya no pasara nada más. No -contestó-, no es cuestión de argumento, hay algunas personas en una calle y las casas y dos automóviles que pasan. Allí estoy yo y un hombre y una mujer cualquiera que sale de un negocio de enfrente y le da un vaso de cerveza. No hay más personas, nosotros tres. El hombre cruza la calle hasta donde sale la mujer de su puerta con la jarra de cerveza y después vuelve a cruzar y se sienta junto a la misma mesa, cerca mío, donde estaba al principio. (1209-1210)

Tenemos, en el mejor de los casos, un conjunto de símbolos elusivos. Más adelante, Blanes averigua y le informa a Langman que el sueño en cuestión no posee ningún

${ }^{13}$ En relación a otros textos de Onetti (Los adioses, Para una tumba sin nombre, "Historia del caballero de la rosa y de la virgen encinta que vino de Liliput”), Ludmer ha comentado que éstos “narran únicamente el proceso de un saber [...], y se cierran siempre en un raro no saber, en un proceso sin resultado: en la parodia -inversión de efectos- del relato policial” (86). Poco más adelante, Ludmer agrega una comparación con el autor de La imagen en el tapiz: "Sólo se narra en James, como en Onetti, la búsqueda de la verdad, nunca la verdad misma: la solución del problema no es otra cosa que la exposición misma de ese problema” (87).

${ }^{14}$ Cito el otro pasaje en que el narrador da expresión a la misteriosa epifanía: "Pero fue entonces que, sin que yo me diera cuenta de lo que pasaba por completo, empecé a saber cosas y qué era aquello en que estábamos metidos, aunque nunca pude decirlo, tal como se sabe el alma de una persona y no sirven las palabras para explicarlo" (Onetti 1217).

Revista Iberoamericana, Vol. LXXVIII, Núm. 241, Octubre-Diciembre 2012, 1025-1040
ISSN 2154-4794 (Electrónico) 
significado preciso para la mujer: "Yo le pregunté qué era esto que íbamos a representar y entonces supe que estaba loca. ¿Le interesa saber? Todo es un sueño que tuvo, ¿entiende? Pero la mayor locura está en que ella dice que ese sueño no tiene ningún significado para ella” (1216).$^{15}$ El vacío semántico declarado no impide, sin embargo, que la narración tome la forma de una búsqueda hermenéutica, pues como hemos dicho ya el sueño pide una interpretación o, si se quiere, el descubrimiento de una semántica del deseo. El verbo "comprender" y sus equivalentes cercanos ("entender”, "descubrir”, "darse cuenta”, "comenzar a saber”) son dichos y vueltos a decir a través del texto bajo distintas formas.

Esa sería, en principio, la historia básica que narra este cuento: una mujer "rara" quiere representar dramáticamente un sueño que tuvo y, en el proceso de realizar ese deseo, que concluye con su propia muerte, el narrador (sólo él, finalmente) dice alcanzar alguna forma de entendimiento. Nuevamente: la comprensión anunciada por Langman se produce más allá de las palabras, en una zona prelingüística resistente a la interpretación donde dominan los símbolos. El sueño, al igual que su representación teatral, despliegan un imaginario simbólico que toma la forma de una escena muda y, en cierto modo, vertiginosa al concluir en ese otro sueño más vasto que es la muerte. Todo muy solipsista, la escena no cuenta con público alguno más allá del narrador que marca bien los límites, su pura condición de observador, escabullándose y escondiéndose entre telones "porque...nada tenía que ver en el disparate que iba a empezar" (1217). La representación es condenada así a un acto sin sentido (un "disparate") o de sentidos incomunicables que se le ofrece al lector. Sólo el pasaje a la escritura, a aquello que puede definirse como texto, permite la interpretación, es decir, la instancia donde la comprensión no es disociable de la explicación.

Como expuse en la primera parte de este trabajo, para una lectura hermenéutica la comprensión del sentido y su validación pasan por la conversión metafórica de la escena simbólica. "Un sueño realizado" es, en este sentido, un texto privilegiado ya que alude, precisamente, a un modo de entendimiento altamente metafórico que revela el carácter creador del lenguaje, su fuerza de producción semántica. Se retrotrae al lector a un locus de saber indisociable de la infancia ("una de esas cosas que se aprenden para siempre desde niño”): el cuento de hadas o infantil maravilloso. ${ }^{16} \mathrm{Y}$ una de las virtudes

15 José Pedro Díaz comenta este pasaje de modo conclusivo: "Es indiscutible [...] que esa escena tiene valor, pero ese valor no puede ser explicado" (109). Y agrega: “[...] se dice allí expresamente que no se puede decir, pero además se explica que alguien puesto en la situación que el relato construye, puede entender no entendiendo” (109-110). Díaz se acerca así al punto nodal de mi interpretación, pero limita finalmente el proceso hermenéutico al escindir dos de sus elementos constitutivos: entender y explicar. Su comentario adopta un punto de vista intradiegético ("alguien puesto en la situación que el relato construye”) que clausura la interpretación, condenándola a repetir tautológicamente los límites establecidos por la narración ("se dice [...] que no se puede decir”).

${ }^{16}$ Para una aproximación a este corpus literario véase: Lerer, Bettelheim y Robert.

Revista Iberoamericana, Vol. LXXVIII, Núm. 241, Octubre-Diciembre 2012, 1025-1040 ISSN 0034-9631 (Impreso)

ISSN 2154-4794 (Electrónico) 
del cuento infantil maravilloso, además de expresar poéticamente el mundo de los hombres y la naturaleza, es la de legar una experiencia, ilustrando un pasaje necesario y costoso. Huelga decir que el arte de Onetti descree de tales sucesiones y deja intacto el enigma alimentado por el relato. El saber final que en aquellas narraciones significa orden y reparación, aquí no tiene lugar. Como comenta astutamente Josefina Ludmer: "el narrador [de Onetti] es el que no sabe, narra porque no sabe...” (124).

He leído "Un sueño realizado" como una versión paródica de "La bella durmiente”. Una bella durmiente al revés, desplazada y enriquecida de otros sentidos; reescrita (soñada) desde las sombras de Hamlet -"A dream itself is but a shadow" (Hamlet II2: 111)-, sobre el que desde el principio del cuento gira una broma "no comprendida del todo" (Onetti 1205) por Langman. ${ }^{17}$ Hamlet como la otra cara de la fábula, una forma de reunir y mantener en tensión términos opuestos: tragedia y cuento de hadas, escepticismo e inocencia, el arte puro de William Shakespeare junto a los sainetes y comedias sentimentales que dirige el mediocre director teatral de este cuento. Vaivenes éstos que definen la escritura de Onetti. Pero también, habría que agregar que la simple mención al teatro de Shakespeare contamina los referentes de esta literatura, haciendo difusas las fronteras entre la realidad y la ficción. ${ }^{18}$ Lo que está afuera del espacio textual, como ha reflexionado Saer (212), quedaría elidido en provecho de una realidad barroca en que la exterioridad es un efecto literario.

La parodia de "La bella durmiente" no es un dato menor en nuestra lectura; su identificación abre el círculo hermenéutico, haciendo visible un conflicto de interpretaciones alrededor de un relato rescatado de la tradición. ${ }^{19}$ Como mostraré, el trabajo de reescritura efectuado implica una resemantización o revisión del los contenidos de la fábula en favor del mito de la virgen adolescente que cruza toda la obra de Onetti.

17 La broma es una invención de Blanes, quien asocia la poca fortuna de Langman a sus sacrificios, desde ya inexistentes, de poner en escena Hamlet. Sentado en la biblioteca del asilo con el libro que rehúsa leer entre las manos, Langman reconoce no haber comprendido nunca totalmente el sentido de la burla de Blanes, pero sí haber intuido "que el Hamlet era el arte, el arte puro, el gran arte, y sabiendo también, porque me fui empapando de eso sin darme cuenta, que era, además, un actor o una actriz, en este caso siempre una actriz con caderas ridículas, vestida de negro con ropas ajustadas, una calavera, un cementerio, un duelo, una venganza, una muchachita que se ahoga. Y, también, W. Shakespeare” (1206).

18 Verani juzga la obra de Shakespeare como "el intertexto privilegiado" (59) del cuento analizado. La presencia de Hamlet le hace subrayar dos aspectos claves de la narrativa onettiana: "la interacción entre la apariencia y la verdad" y el "carácter teatral” de ésta (59). Explica Verani: "Las reminiscencias de un drama que responde a mecanismos de ocultamiento y simulacro, a imprevistas invenciones y desdoblamientos que ponen en juicio toda la realidad, guían, implícitamente, la lectura de "Un sueño realizado" (59).

19 Hay varias versiones de esta fábula. Las primeras que se conocen son la francesa, "Histoire de Troylus et de la belle Zellandine” (Perceforest, siglo xIV) y la catalana "Frère de joie, soeur de plaisir" (siglo XvI), ambas anónimas. Consulté para mi estudio la versión de Basile, "Sole, Luna e Talia” (Pentamerone, 1636), y aquéllas bien conocidas de Perrault, "La belle au bois dormant" (1697) y de los hermanos Grimm, “Dornröschen” (1812).

Revista Iberoamericana, Vol. LXXVIII, Núm. 241, Octubre-Diciembre 2012, 1025-1040
ISSN 2154-4794 (Electrónico) 
Gracias a la duplicación referencial -la superposición de ambas durmientes, la del modelo o hipotexto y la del hipertexto o texto productor- se activa la fuerza sugestiva del enigmático personaje femenino de "Un sueño realizado":

La mujer tendría alrededor de cincuenta años, y lo que no podía olvidarse en ella [...] era aquel aire de jovencita de otro siglo que hubiera quedado dormida y despertara ahora un poco despeinada, apenas envejecida, pero a punto de alcanzar su edad en cualquier momento, de golpe, y quebrarse allí en silencio, desmoronarse roída por el trabajo sigiloso de los días. (1207)

El contrapunto intertextual desvía las versiones de Perrault y de los Grimm hacia un comentario sobre el poder destructor de la edad y la pérdida de la pureza, convirtiendo la imagen de la "loca” o "jovencita envejecida” de Onetti en algo que podría pensarse cercano a un concepto. ${ }^{20}$ Ocurre así, por ejemplo, cuando Perrault incurre en la descripción de algunos detalles vestimentarios de la princesa y emite juicios sobre su belleza: "Le prince aida la Princesse a se lever; elle était toute habillée et fort magnifiquement; mais il se garda bien de lui dire qu'elle était habillée comme ma mère-grande, et qu'elle avait un collet monté: elle n'en était pas moins belle” $(136)^{21}$-lo cual da lugar a la siguiente precisión: "Tenía el pelo casi gris peinado en trenzas enroscadas y su vestido correspondía a una vieja moda; pero no era el que se hubiera puesto una señora en los tiempos en que fue inventado, sino también esto, el que hubiera usado entonces una adolescente" (Onetti 1207). ${ }^{22}$

También, ante la descripción que hace Perrault de los sueños de la princesa: “[...] pendant un si long sommeil, lui avait procuré le plaisir des songes agréables” (9)-Onetti vuelve a corregir: "Dice que mientras dormía y soñaba eso era feliz, pero no es feliz la palabra sino otra clase de cosa. Así que quiere verlo todo nuevamente” (1216).

20 Ver Albouy 221.

${ }^{21}$ Bettelheim hace una crítica de este pasaje que resulta pertinente a nuestra lectura: "Les détails de la robe, par exemple, détruisent la notion du temps mythique, allegorique et psychologique qui est suggéré par les cent années de sommeil: il en fait un temps chronologique précis [...]. Perrault annihilait le sentiment de intemporalité qui est un élément important de l'éficacité des contes de fées” (340).

${ }^{22}$ Verani ve una clara analogía entre la mujer de "Un sueño realizado” y Ofelia, con quien compartiría "la timidez, puerilidad y 'locura' [...] Hay datos [prosigue Verani] que aparecen invertidos: su cabello rubio, suelto y sensual es ya gris y está peinado en trenzas enroscadas. Un detalle tangencial es más sugerente y central: el simbolismo floral, que acompaña a Ofelia desde su primera escena hasta su entierro; aparece siempre con una guirnalda de flores en la cabeza y se ahoga coronada de 'guirnaldas fantásticas' de flores silvestres. La mordaz inventiva de Onetti condena a 'la rosa de mayo' (IV.v.155), como la llama su hermano Laertes, a llevar 'una rosa en la cintura, tal vez artificial ahora que pienso' (OC: III, 46)” (62). A continuación, en el cuerpo del texto, propongo una referencia intertextual complementaria a la notada por Verani.

Revista Iberoamericana, Vol. LXXVIII, Núm. 241, Octubre-Diciembre 2012, 1025-1040 ISSN 0034-9631 (Impreso) 
En cuanto a los hermanos Grimm, a quienes nuestro autor rendirá años más tarde un homenaje en Para una tumba sin nombre, encarnados significativamente en la figura del dueño de una funeraria (aquél que se ocupa del ritual de pasaje), recogieron la fábula que nos ocupa y dieron a su versión el título de Dornröschen (pequeña rosa de espinas), forma diminutiva que bautiza a la princesa y, al mismo tiempo, alude al cerco protector que llegado el momento se convertirá en "belles et grandes fleurs qui s’ouvrirent d'elles mêmes” (11). "Un sueño realizado” se refiere, en cambio, a una rosa “artificial” y amenazante que introduce nuevamente la tensión interpretativa: "La blusa tenía encajes y era ajustada, con un gran camafeo entre los senos agudos de muchacha, y la blusa y la pollera se unían y estaban divididas por una rosa en la cintura, tal vez artificial ahora que pienso, una flor de corola grande y cabeza baja, con el tallo erizado amenazando el estómago" (1207). Considero innecesario detenerme sobre la obvia connotación sexual del pasaje.

La narración va siendo puntuada por el dormir y el despertar de cada uno de los personajes hasta terminar en el sueño/muerte de la mujer, esto es, en una completa inversión del desenlace de la fábula. Subyacente a los ciclos del sueño y de la vigilia se despliega en el cuento el enfrentamiento que libran el deseo y la realidad. De allí, las muchas menciones a la "locura" de la mujer (a su voluntad inquebrantable de realizar el sueño) que Blanes, el galán de esta historia, relativiza en un momento con palabras que toma prestadas de Polonio ("Though this be madness, yet there is a method in't”, Hamlet II-2: 109): "Y aunque es una locura, tiene su cosa razonable” (1216). Mientras en el día duerme el deseo, la noche desencadena la imaginación deseante: la ceremonia propiciatoria comienza pasadas las diez de la noche y persigue la recuperación (por supuesto, imposible en el plano de la realidad fáctica) de una edad perdida; el instante en que la mujer vuelve a encontrarse con la muchacha que ella fue un día. ${ }^{23}$

Junto a los efectos paródicos de esta literatura escrita sobre literatura, se produce la mitografía onettiana. La duplicación de la función referencial en “Un sueño realizado”-la metafórica durmiente que el autor multiplicando alusiones le hace descubrir al lectorconvierte el texto en una forma a la vez reconocible y extraña que desafía el entendimiento

${ }^{23}$ Intento similar guía a Linacero en El pozo cuando hace caminar a su mujer por la rambla nocturna esperanzado en rescatar la adolescente de anataño o "una imagen exacta que ya no podía ser recordada" (64). También allí, inicialmente, se busca el pasado en el sueño, llamándoselo con una "caricia monótona" que veremos repetirse en la cabellera de la mujer de "Un sueño realizado.” Pero el ritual resulta igualmente infructuoso: "Había una esperanza, una posibilidad de tender las redes y atrapar el pasado y la Ceci de entonces. Yo no podía explicarle nada: era necesario que ella fuera sin plan, no sabiendo para qué. Tampoco podía perder tiempo, la hora del milagro era aquella, en seguida. Todo esto era demasiado extraño y yo debía tener cara de loco. Se asustó y fuimos. Varias veces subió la calle y vino hacia mí con el vestido blanco, donde el viento golpeaba haciéndola inclinarse. Pero allá arriba en la calle empinada, su paso era distinto, reposado y cauteloso, y la cara que acercaba al atravesar la rambla debajo del farol era seria y amarga. No había nada que hacer y nos volvimos” (65).

Revista Iberoamericana, Vol. LXXVIII, Núm. 241, Octubre-Diciembre 2012, 1025-1040
ISSN 2154-4794 (Electrónico) 
del lector y lo incita a encontrar nuevas significaciones. Esto sería lo propio del mito: una estructura doble que, de acuerdo a la definición de Roland Barthes, produce "un juego de escondidas" entre el sentido y la forma. ${ }^{24} \mathrm{El}$ texto solicita la participación del lector y se burla de las expectativas o, más precisamente, de los prejuicios que resultan de su colocación dentro de una tradición. Al igual que entre Blanes y Langman planea a lo largo del cuento una broma "no comprendida del todo" (1205). De este modo, la literatura de Onetti conduce al lector hacia una hermenéutica de la sospecha que asume el prejuicio como condición de posibilidad de la comprensión (Gadamer) y, a su vez, lo incita a emprender una crítica que socave la autoridad de la tradición, lo cual ha sido la punta de lanza de la mayoría de los cuestionamientos dirigidos al autor de Verdad y método.

El cuento sigue un curso contrario a los recuerdos. Son introducidos conceptos que deforman la antigua fábula, sin que ésta desaparezca en ningún momento del horizonte del lector. Junto a Barthes, podríamos hablar de una "supervivencia insidiosa" que tiene consecuencias ineludibles en el campo de la significación. Apropiándose de "La bella durmiente" y librándola a una serie de operaciones textuales -invirtiéndola, ornamentándola, cruzándola con Hamlet e imponiéndole un tono irónico; finalmente, desmitificándola-, Onetti anuncia (vuelve a anunciar) y hace "comprensible" el mito personal de la virgen adolescente con la que irrumpe la nostalgia de una edad perdida donde el sueño y la realidad mezclaban sus aguas.

Superpuesta a esta mitografía se encuentra lo que llamo la autorrepresentación del mito. Si concordamos con Northrop Frye que el mito representa la fusión del sueño y el ritual bajo la forma de una expresión verbal que les da significación, puede convenirse que "Un sueño realizado" mima este proceso. Tenemos un sueño por realizar (hacerlo plausible, aceptable, al espíritu del lector) y un ritual que lo desarrolla: el sueño/deseo traído por la mujer y la obra de teatro que oficiaría el pasaje (en clara inversión del despertar adolescente celebrado por la fábula infantil, pues como se sabe todo acaba con la muerte de la mujer). Como en Hamlet, l'oeuvre en abyme va a desempeñar una función reveladora; gracias a ella el narrador comienza a comprender el sentido de la representación. Aunque en esto, conviene trascender lo enunciado y prestar atención, como hiciera Ludmer en su importante libro sobre Onetti, al acto de la enunciación y

${ }^{24}$ Barthes presenta un análisis estructural del mito al que define como el encuentro de dos sistemas semiológicos; el sentido del primero de estos sistemas es apropiado y convertido en significante de un nueva cadena de significación. De esta manera, identifica en el mito una reunión de concepto e imagen que es útil recordar aquí: "Pour garder une métaphore spatiale dont j’ai déjà souligné le caractère approximatif, je dirai que la signification du mythe est constituée par une sorte de tourniquet incessant qui alterne le sens du signifiant et sa forme, un langage-objet et un méta-langage, une conscience purement signifiante et une conscience purement imageante; cette alternance est en quelque sorte ramassée par le concept qui s'en sert comme d'un signifiant ambigu, à la fois intellectif et imaginaire, arbitraire et naturel" (208).

Revista Iberoamericana, Vol. LXXVIII, Núm. 241, Octubre-Diciembre 2012, 1025-1040 ISSN 0034-9631 (Impreso) 
a los procesos de construcción del relato que tienen como condición de posibilidad un corte con la realidad fáctica, exterior al texto (19). Desde estos parámetros, se entiende la elección del mito, el más abstracto de los modos literarios, que opuesto a las vanas similitudes del realismo apunta a un saber "inexplicable” de carácter simbólico. ${ }^{25}$ Arte de conversión metafórica, la mitografía de Onetti recusa la traducción del sentido, preservando la vinculación y el poder que tiene el símbolo de tocar las fibras más escondidas de la vida humana.

Amodo de conclusión: “Un sueño realizado” se escribe a partir de un relato rescatado de la tradición, una suma de valores intelectivos e imaginarios que en sus orígenes crecía bajo espesas sombras. Con el tiempo, ese saber se naturaliza y es banalizado: la princesa durmiente y el príncipe redentor se vuelven fáciles presas del sentimentalismo banal. La bella durmiente enseña el tiempo de la espera, un tiempo necesario (siempre hay en las fábulas una lección de carácter ético o moral): la espera secular del amor que Bettelheim interpreta como el gesto optimista de esta historia. ${ }^{26}$ Onetti descree de tales sucesiones de sentido y emprende un trabajo de desmitificación para construir, a su vez, su propio mito. Los recuerdos del lector serán burlados una y otra vez: el príncipe deviene un ruin y alcohólico galán, Blanes, quien, al igual que el narrador, está condenado a vivir en la necesidad material. El comercio sexual de aquél con la mujer precipitarían ésta a la muerte -a su ofelización podría decirse, dada la carga simbólica que comunican la cabellera y la caricia infatigable que se enreda en ella al fin de la obra representada-. ${ }^{27}$ El poeta D’ Annunzio, recuerda Bachelard, ya había transitado una escena similar, donde el repetitivo gesto en los cabellos es encantamiento que sugiere la evocación del pasado, un transporte al fondo de los tiempos. ${ }^{28}$ Acuerdo armonioso éste

25 "Le mythe constituerait donc une forme de pensée permettant d'appréhender une realité mal connue ou peu connaissable, fascinante ou redoutable, voir inavouable. Il jouerait un rôle de compensation, analogue à celui du rêve, peut-être, soit qu'il permette à la pensée de s'élancer hors de limites de la raison, soit qu'il substitue à une réalité pénible une image qui la rende exaltante”, véase Albouy (269).

${ }^{26}$ En su interpretación del contenido pedagógico de la fábula, Bettelheim llama la atención sobre el tiempo que dista entre el despertar sexual de la adolescente (las gotas de sangre, el descubrimiento del huso y la curiosidad encendida por éste) y el momento de la realización del acto, simbolizado por el beso. Se congraciaría, de este modo, a la adolescente con la espera. En la versión de Basile, en cambio, el príncipe posee a la princesa mientras duerme, ésta dará a luz siempre dormida y despertará sólo cuando sea llamada a alimentar a su criatura. Ramificaciones de una fábula que Onetti quizás conocía.

27 La escena es presenciada por Langman, quien fija su mirada en "la mano de Blanes que seguía acariciando la frente y la cabellera desparramada de la mujer, sin cansarse, sin darse cuenta de que la escena había concluido y que aquella última cosa, la caricia en el pelo de la mujer, no podía continuar siempre. Con el cuerpo inclinado, Blanes acariciaba la cabeza de la mujer, alargaba el brazo para recorrer con los dedos la extensión de la cabellera gris desde la frente hasta los bordes que se abrían sobre el hombro y la espalda de la mujer acostada en el piso" (1218-1219).

${ }^{28}$ D'Annunzio es otro autor a considerar dentro del palimpsesto onettiano; véase el siguiente fragmento de Forse che si, forse che no: "Le passage répété du peigne dans la masse de ses cheveux était comme une incantation qui eût duré depuis toujours, qui devait continuer sans fin” (Bachelard 116).

Revista Iberoamericana, Vol. LXXVIII, Núm. 241, Octubre-Diciembre 2012, 1025-1040
ISSN 2154-4794 (Electrónico) 
con el fin perseguido por el ritual de "Un sueño realizado": la convocación de una edad perdida o imposible recuperación de la muchacha. ${ }^{29}$ Onetti en éste, como en muchos otros escritos suyos, muestra su desasosiego y escepticismo frente a ese pasaje. Es en el clima misteriosamente trascendente del ritual que la narración pareciera acceder al punto más cercano de su búsqueda, abriendo un mundo no ostensible de comprensión en que el lector podría, eventualmente, habitar.

Rasgo de la modernidad: la experiencia ha desaparecido y la verdad se vuelve incomunicable. Acaso, podría decirse con Benjamin o Blanchot, el único momento en que se restituye la experiencia sea en esa relación que liga la escritura a la muerte entendida como suprema indeterminación. Pienso que la narrativa de Onetti se constituye en este escenario filosófico por excelencia. Y viene a cuenta recordar que Gadamer entendía la hermenéutica como una experiencia de la finitud o tragedia humana, el entendimiento doloroso de su condición limitada abierto por la literatura. El aprendizaje de Linacero, Díaz Grey, Jorge Malabia y demás narradores del corpus sería, desde esta perspectiva, asimilable a una experiencia de la pérdida: la comprensión de algo inexplicable.

\section{OBRAS CITADAS}

Albouy, Pierre. Mythographies. París: Librairie José Corti, 1976.

Bachelard, Gaston. L'eau et le rêve. París: José Cortí, 1942.

Balaguer, Vicente. La interpretación de la narración. La teoría de Paul Ricoeur. Pamplona: Universidad de Navarra, 2002.

Barthes, Roland. "Le mythe aujourd’hui.” Mythologies. París: Seuil, 1957. 193-247.

Basile, Giambattista. The Pentameron. Londres: Spring Books, 1955.

Benjamin, Walter. "El narrador". Para una crítica de la violencia y otros ensayos. Roberto Blatt, trad. Madrid: Taurus, 1991.

Bettelheim, Bruno. Psychanalyse des contes de fées. París: Robert Lafont, 1976.

Blanchot, Maurice. "L'oeuvre et l'espace de la mort." L'espace littéraire. París: Gallimard, 1955. 99-211.

Chartier, Roger. “Poderes y límites de la representación. Marín, el discurso y la imagen”.

Escribir las prácticas. Foucault, De Certeau, Marín. Horacio Pons, trad. Buenos

Aires: Ediciones Manantial SRL, 2006. 73-99.

Díaz, José Pedro. “Sobre Juan Carlos Onetti”. Juan Carlos Onetti. Hugo J. Verani, ed. Madrid: Taurus, 1987. 92-114.

Durand, Gilbert. Les structures anthropologiques de l'imaginaire. París: Bordas, 1984.

${ }^{29}$ No está de más recordar que Gilbert Durand ve la cabellera de Ofelia flotando en el agua oscura como la simbolización de una feminidad embrionaria.

Revista Iberoamericana, Vol. LXXVIII, Núm. 241, Octubre-Diciembre 2012, 1025-1040
ISSN 2154-4794 (Electrónico) 
Ferro, Roberto. Onetti/La fundación imaginada. La parodia del autor en la saga de Santa María. Córdoba: Alción Editora, 2003.

Frye, Herman Northrop. Anatomy of Criticism: Four Essays. Princeton: Princeton UP, 1957.

Gadamer, Hans-Georg. Verdad y método. Fundamentos de una hermenéutica filosófica. Salamanca: Sígueme, 1977.

Grimm, Jacob y Wilhelm Grimm. Contes. París: Gallimard, 1973.

Lerer, Seth. "Convertir la paja en oro”. La magia de los libros infantiles. De las fábulas de Esopo a las aventuras de Harry Potter. T. de Lozoya y J. Rabasseda, trads. Barcelona: Ares y mares, 2009. 325-352.

Ludmer, Josefina. Onetti. Los procesos de construcción del relato. Buenos Aires: Sudamericana, 1977.

Onetti, Juan Carlos. Obras completas. México D. F.: Aguilar, 1970.

Perrault, Charles. Contes. París: Éditions Gallimard, 1981.

Premat, Julio. "Relato y deseo en las novelas cortas de Onetti: una lectura de Para una tumba sin nombre”. Juan C. Onetti. Novelas cortas. Daniel Balderston, coord. Poitiers/Córdova: CRLA-Archivos, 2009. 519-538.

Rama, Ángel. "El narrador ingresa al baile de máscaras de la modernidad”. Juan Carlos Onetti. El escritor y la crítica. Hugo J. Verani, ed. Madrid: Taurus, 1987. 75-91. "Origen de un novelista y de una generación literaria”. Juan C. Onetti. Novelas cortas. Daniel Balderston, coord. Poitiers/Córdoba: CRLA-Archivos, 2009. 662-688.

Ricoeur, Paul. "Rhétorique - Poétique - Herméneutique”. De la Métaphysique à la rhétorique: essais à la memoire de Chaïm Perelman avec un inédit sur la logique. Bruxelles: Éditions de l’ Université de Bruxelles, 1986. 143-155.

Teoría de la interpretación. Graciela Monges Nicolau, trad. México D. F.: Siglo XXI, 1995.

Hermenéutica y acción. De la hermenéutica del texto a la hermenéutica de la acción. Buenos Aires: Prometeo Libros, 2008.

Robert, Marthe. "Préface”. Jacob Grimm y Wilhelm Grimm. Contes. París: Éditions Gallimard, 1973.

Saer, Juan José. “El soñador discreto”. Trabajos. Buenos Aires: Seix Barral, 2005. 207-238. "Onetti y la novela breve.” Trabajos. Buenos Aires: Seix Barral, 2005. 243-251.

Shakespeare, William. Hamlet. Londres: Penguin Books, 1980.

Verani, Hugo J. Onetti: el ritual de la impostura. Montevideo: Trilce, 2009.

Revista Iberoamericana, Vol. LXXVIII, Núm. 241, Octubre-Diciembre 2012, 1025-1040
ISSN 2154-4794 (Electrónico) 